Integrated geo-informational framework for the geologic-geophysical data analysis and its application to the south part of the Siberian platform

*S. Malinina, (VNIIGeosystems)

SUMMARY

Magnetic and gravitational fields processing and interpretation, as well as the results interconnection with the seismic and electrical prospecting and drilling, considerably widen this fields application capabilities for a region geology study and increase the reliability of the structural imaging based on the basement and other Earth crust interfacial areas.

In this report integrated geo-informational framework and the results of its approbation on the south part of the Siberian platform materials are presented. Material constitution and basement structure elaboration was carried out using this integrated framework. This elaboration was based on the retrospective material analysis, gravitational and magnetic fields transformations calculation, geomagnetic inverse problem solution, magnetic field volumetric modeling. Volumetric magnetic model of the south part of the Siberian platform, surface geometry and material constitution scheme were obtained.

3-D models of effective density and magnetization distribution along the south part of the Siberian platform were built for the purpose of deep territory structure using filtration and analytical magnetic and gravitational fields extensions up and down methods. Geologic-geophysical crosssections were built based on models complex analysis, that were obtained by various geophysical methods along the South Siberian platform CMP profiles 1-SB, 2-SB and 3-SB.

\title{
Єдине геоінформаційне середовище для аналізу геолого- геофізичних даних на прикладі південної частини Сибірської платформи
}

*C.С. Малініна, (Всеросійський науково-дослідний інститут геологічних, геофізичних $i$ геохімічних систем (ВНИИгеосистем))

\section{PЕЗЮМЕ}

Обробка та інтерпретація магнітних і гравітаційних полів, а також комплексування результатів 3 даними сейсморозвідки, електророзвідки та буріння значно розширюють можливості застосування цих методів для вивчення геологічної будови регіону і підвищують надійність структурних побудов по фундаменту і інших поверхонь розділу земної кори.

У доповіді представлена єдине геоінформаційне середовище, що дозволяє проводити комплексний аналіз геолого-геофізичних даних з метою вивчення геологічної будови території та результати її апробації на матеріалах південної частини Сибірської платформи.

У єдиному геоінформаційному середовищі проведено уточнення речовинного складу та будови фундаменту і осадового чохла на основі аналізу ретроспективного матеріалу, розрахунку трансформацій гравітаційного і магнітного полів, розв'язку оберненої задачі магніторозвідки, об'ємного моделювання магнітного поля. При цьому отримана об'ємна

\section{$\mathrm{X}^{\text {th }}$ International Conference on Geoinformatics - Theoretical and Applied Aspects}


магнітна модель по південній частині Сибірської платформи, схема рельєфу поверхні і речовинного складу фундаменту.

3 метою вивчення глибинної будови території побудовані 3-D моделі розподілу ефективної щільності та намагніченості по південній частині Сибірської платформи методами фільтраційних і аналітичних продовжень гравітаційного і магнітного поля вгору і вниз. За профілями МЗГТ півдня Сибірської платформи 1-СБ, 2-СБ і 3-СБ побудовані геолого-геофізичні розрізи на основі комплексного аналізу моделей, отриманих різними геофізичними методами (сейсморозвідкою МЗГТ, електророзвідкою МТ3, гравірозвідкою і магніторозвідкою).

\section{Единая геоинформационная среда для анализа геолого-} геофизических данных на примере южной части Сибирской платформы

*C.С. Малинина, (ФГУП ГНЦ РФ ВНИИгеосистем)

\section{РЕЗЮМЕ}

Обработка и интерпретация магнитных и гравитационных полей, а также комплексирование результатов с данными сейсморазведки, электроразведки и бурения значительно расширяют возможности применения этих методов для изучения геологического строения региона и повышают надежность структурных построений по фундаменту и другим поверхностям раздела земной коры.

В докладе представлена единая геоинформационная среда, позволяющая проводить комплексный анализ геолого-геофизических данных с целью изучения геологического строения территории и результаты ее апробации на материалах южной части Сибирской платформы.

В единой геоинформационной среде проведено уточнение вещественного состава и строения фундамента и осадочного чехла на основе анализа ретроспективного материала, расчета трансформаций гравитационного и магнитного полей, решения обратной задачи магниторазведки, объемного моделирования магнитного поля. При этом получена объемная магнитная модель по южной части Сибирской платформы, схема рельефа поверхности и вещественного состава фундамента.

C целью изучения глубинного строения территории построены 3-D модели распределения эффективной плотности и намагниченности по южной части Сибирской платформы методами фильтрационных и аналитических продолжений гравитационного и магнитного поля вверх и вниз. По профилям МОГТ юга Сибирской платформы 1-СБ, 2-СБ и 3-СБ построены геологогеофизические разрезы на основе комплексного анализа моделей, полученных различными геофизическими методами (сейсморазведкой МОГТ, электроразведкой МТЗ, гравиразведкой и магниторазведкой). 